\title{
Sobre tradição e inovação na ciência histórica alemã: entrevista com Ulrich Muhlack
}

On tradition and innovation in the German historical science: interview with Ulrich Muhlack

\section{Renata Maria Pistilli Eberhard}

renatapistilli@gmail.com

Doutoranda

Johann Wolfgang Goethe-Universität Frankfurt am Main

Rua Cel. Marcondes de Mattos, 140 - Quiririm

12043-280 - Taubaté - SP

Brasil

Palavras-chave

História da historiografia; Historicismo; Escola de Bielefeld.

Keywords

History of historiography; Historicism; Bielefeld School. 
Ao leitor brasileiro, Ulrich Muhlack talvez seja conhecido sobretudo como o responsável pela edição das cartas de Leopold von Ranke, ou ainda como estudioso deste autor. Esta é, no entanto, apenas uma parte do amplo espectro de atividades e temas aos quais dedicou-se ao longo de sua carreira. Desde 2006 professor aposentado da Johann Wolfgang Goethe-Universität, ocupou por 34 anos nesta universidade a cadeira de Metodologia e História da Historiografia e dedicou-se em suas aulas e pesquisas a temas como o Renascimento, o Humanismo e as relações entre história política e historiografia. Participou ativamente dos inúmeros debates e colóquios acerca dos temas teoria de história e história da historiografia, desencadeados principalmente pela ascensão no cenário intelectual alemão na década de setenta da ciência social histórica e foi, durante anos, autor de balanços bibliográficos para importantes revistas científicas da área de História. É também autor de uma obra extensa, na qual se destaca sobretudo seu livro sobre a pré-história do historicismo, assim como muitos artigos sobre este tema.

1. Renata Maria Pistilli Eberhard: O senhor nasceu em Königsberg. Esta cidade, enquanto cidade de Kant, chegou a ter alguma influência sobre sua escolha profissional ou houve outros acontecimentos - o senhor nasceu durante a Segunda Guerra Mundial e cresceu no período pós-guerra - que o marcaram e o levaram para as ciências humanas?

14 Ulrich Muhlack: Königsberg sempre teve um grande significado para mim. Ali eu passei minha primeira infância, tendo saído de lá com quatro anos, em setembro de 1944, e desde então, Königsberg sempre foi um tema importante em minha família. Era um lugar do qual meus pais sentiam muita saudade e, por causa disto, eu também sempre me interessei por esta cidade. No entanto, não poderia dizer que minha dedicação à história ou minha escolha profissional estivessem ligadas de alguma forma e este meu interesse. Importantes foram determinadas experiências políticas do pós-guerra; estes assuntos já me interessavam em meu tempo de escola e influenciaram, até um certo ponto, meu interesse por história e meu trabalho posterior.

2. RMPE: O senhor estudou em Göttingen e em Frankfurt am Main. Pode-se dizer de muitas universidades alemãs, que elas estão ligadas a determinadas tradições científicas. Como o senhor caracterizaria estas duas instituições? $O$ senhor as escolheu por um motivo específico?

Ulrich Muhlack: Comecei meus estudos universitários em Frankfurt am Main, na Universidade Johann von Goethe por razões bem práticas: naquela época eu vivia em Frankfurt, ali eu havia frequentado a escola, em um ginásio nesta cidade eu havia feito meu exame de conclusão do segundo grau, e para mim, era a opção mais viável, que eu começasse meus estudos universitários ali. Muito diversa foi a situação quando me mudei pra Göttingen. Estudei por um ano em Göttingen por uma razão muito específica: porque a universidade de 
Göttingen naquela época era tida como o grande templo da ciência histórica alemã. Ali lecionavam historiadores famosos como Hermann Heimpel, Alfred Heuss, Reinhard Wittram, Percy Ernst Schramm, os quais já me eram conhecidos desde meus tempos de escola. Por esta razão eu queria muito assistir suas aulas e aprender com eles. No entanto, acabei não permanecendo em Göttingen, embora Heuss me encorajasse a fazê-lo, e sim, voltei para Frankfurt. É que nos meus primeiros semestres ali eu tinha encontrado em Otto Vossler um professor que havia me fascinado e para o qual eu queria voltar de qualquer maneira. Em contato com ele eu continuei e concluí meus estudos de história.

3. RMPE: O senhor acabou de entrar em nosso próximo tema. Como o senhor caracterizaria a influência destas universidades sobre o senhor? Houve professores que o marcaram de forma especial? O senhor já mencionou Vossler, poderia agora contar algo mais sobre esta influência?

Ulrich Muhlack: Então, primeiramente queria fazer uma observação de caráter mais geral: tive a oportunidade de realizar meus estudos em uma época maravilhosa. Na verdade, estudei ainda em estilo humboldtiano, em uma época em que as universidades ainda eram totalmente preenchidas pelo espírito humboldtiano. Nelas predominava um espírito de total liberdade; havia um mínimo de regras, o qual, na verdade, resultava da própria lógica das disciplinas. É claro que havia uma diferença entre seminários introdutórios e seminários, ou ainda, seminários para estudantes em final de curso. ${ }^{1}$ Esta sequência era respeitada. Eu, por exemplo, estudei além de História, Latim. Neste curso tínhamos que fazer provas, claro. Mas, de maneira geral, nos era dada total liberdade, cada um podia conduzir seus estudos da maneira que queria. A cada um era dada a chance de compor sua própria grade de atividades. E, quando o aluno tinha a sensação de que já havia aprendido o suficiente, então ele se submetia aos exames finais. Não havia provas de qualificação, ${ }^{2}$ não havia provas no final do semestre, cada um era totalmente responsável por si próprio. Escrevia-se trabalhos, quando se queria, e eles eram naturalmente valorados pelos professores, e isso fazia com que progredíssemos em nossos conhecimentos. No meu caso, eu gostava sobretudo das aulas-conferência. Nestas encontrei meus professores mais importantes. Em Otto Vossler, por exemplo, me impressionava como ele refletia e esgotava os temas de suas aulas. Seu ciclo de conferências, que ia da Reforma até o início do século $\mathrm{XX}$, era constituído por aulas panorâmicas de conteúdo totalmente refletido, repletas de clareza didática. De outro lado também, Alfred

\footnotetext{
${ }^{1}$ No sistema universitário alemão é feita uma diferença entre a aula ou preleção (Vorlesung), no qual o professor detém a palavra na maior parte do tempo, e os seminários, onde os alunos, a partir de determinados temas dados pelo professor, preparam e conduzem os acontecimentos nas salas-de-aula. Também os seminários, por sua vez, são divididos entre Seminários Introdutórios (Proseminar), Seminários (Seminar) e Seminários para estudantes na fase final dos estudos (Hauptseminar). Além destes dois tipos de atividades, existem ainda os Exercícios (Übungen), onde são treinadas determinadas habilidades práticas (como por exemplo traduções e gramática, nos cursos de Letras).

2 O estudo universitário hoje em dia na Alemanha é dividido em duas etapas: uma etapa introdutória e uma etapa final. Entre as duas o aluno deve fazer uma prova intermediária (Zwischenprüfung), a qual denomine acima de "prova de qualificação". Somente quem faz esta prova com sucesso pode passar à etapa seguinte.
} 
Heuss, o qual lecionava uma outra disciplina, História Antiga, e que conseguia expor de uma maneira totalmente nova os temas sobre os quais ele falava, apresentando-os de maneira totalmente inédita, mesmo quando estava falando de dados históricos já conhecidos, os quais ele articulava de maneira inovadora. Essas foram, portanto, as figuras importantes, as personalidades que me marcaram, claro que dentro desta moldura de uma universidade livre em estilo humboldtiano. Eu mesmo tentei utilizar mais tarde, nas minhas atividades enquanto professor, o que havia aprendido com eles.

4. RMPE: Voltando mais uma vez a Vossler. Sobre ele o senhor disse uma vez que em todos os seus escritos, embora ele tivesse se ocupado de temas diversos ao longo de sua vida, podia ser identificada uma linha mestra, que era a da "história do pensamento ocidental moderno sobre a liberdade", o qual por sua vez podia ser reconduzido à sua "reflexão sobre a substância histórica da vida política do presente". Também houve uma questão que sempre esteve por trás dos temas com os quais o senhor se ocupou?

Ulrich Muhlack: De maneira geral, deve-se evitar estilizar o próprio processo de formação. Eu não posso dizer que eu tenha tido um problema fixo desde o princípio. Também com Vossler não foi assim. Sua questão de fundo foi se constituindo no decorrer de sua vida profissional. No meu caso dá-se o mesmo. Eu sempre tive, desde meus tempos de escola, muito interesse pelo universo da história, ele me atraía. Também a leitura de lendas de todos os tipos acabou por reforçar esse interesse. Todas essas coisas me fascinavam, sem que eu me perguntasse, que significado aquilo tudo tinha. O universo da história, por si mesmo, era fascinante para mim, e, desta fascinação, se deu minha decisão de estudar História. Se se quisesse trazer todas essas experiências para um denominador comum, poder-se-ia dizer que, desde meus tempos de universitário, fui aprendendo cada vez mais a ver com clareza, a compreender o significado da história para o presente, bem como a relação com o presente de qualquer pesquisa histórica. Isso tornou-se, poderia dizer assim, um tema geral, uma linha condutora de meus estudos históricos. Na verdade, ocupei-me com temas diversos, no começo com história política, com história política das ideias, posteriormente com temas de história da cultura como o Humanismo e a Renascença. Também dediquei-me à teoria da história, à história da historiografia, e estes dois temas acabaram tornando-se meu campo principal de trabalho ao longo de décadas. Todos estes são campos temáticos diversos, entre os quais existem diferentes elos de ligação, não preciso entrar aqui em detalhes. Mas todos estes campos eu pratiquei sempre sob o prisma daquela ideia norteadora: sempre tendo em mente o significado de cada pesquisa histórica para o presente, como orientação para o presente.

5. RMPE: Esta temática vem muito ao encontro da próxima questão, a qual gostaria de abordar: o senhor se formou como historiador nos anos sessenta, em um momento em que um grupo de historiadores na Alemanha pleiteava 
uma "história além do historicismo". O senhor, ao contrário, entende-se como um herdeiro daquela tradição científica. Como foi trilhar tal caminho naquele momento, ou ainda, como eram as discussões entre essas duas concepções da ciência histórica? O senhor disse há pouco que sempre se interessou pelo presente. Mas trilhou um caminho diverso daquele trilhado por aquele grupo...

Ulrich Muhlack: Houve realmente um grande embate naquele momento. De um lado havia aqueles que queriam ultrapassar o historicismo. Eles queriam ultrapassá-lo naquilo que se referia ao método, queriam deixar para trás a simples narração factual, queriam deixar para trás o ponto de vista das individualidades e, por último, queriam deixar para trás a história política. Eles aspiravam, no lugar disto, a conteúdos e métodos totalmente novos. Importante para eles eram, sobretudo, os campos da história econômica e social; por isso eles se entendiam como representantes de uma ciência social histórica, mais tarde falaremos ainda sobre esse tema. Tudo isso direcionava-se, tanto no que concerne aos temas, como no que concerne aos métodos, contra o historicismo. Para mim ficou claro, desde o início, que um movimento renovador desse tipo, a princípio, tinha sua razão de ser; sempre houve inovações na história da ciência histórica, ocasionadas por novos desafios. Mas, em muitos aspectos, o ataque ao historicismo me parecia injusto. Censurava-se nele coisas pelas quais, a meu ver, não se deveria censurá-lo. Simplificava-se por demais as coisas. Construía-se uma imagem do inimigo para, em seguida, construir a própria em oposição àquela. Surgia, assim, na minha maneira de ver as coisas, uma polaridade desequilibrada, uma oposição não calcada na realidade. Contrariamente a esta posição, a mim era importante exatamente, a partir dos novos desafios do presente, fortalecer o historicismo e mostrar seus potenciais tornando, assim, algumas das críticas a ele desnecessárias. $E$, pelo fato disto ser tão importante para mim, voltei-me para a sua história. Passei a questionar como ele havia se formado, quem haviam sido seus fundadores, quais eram suas principais vertentes. E, neste processo, tornou-se mais claro ainda para mim que o historicismo era mais do que aquela imagem que se fazia dele naquele momento. Só para citar um exemplo: houve no século XIX uma Escola Histórica da Economia Política, uma vertente do historicismo, a qual se ocupava com temas de história social e econômica. Certamente de maneira diferente daquela do presente, mas, de qualquer forma, de maneira que tais temas estivessem em seu horizonte de preocupações. Esse era meu objetivo naquele momento e eu gostaria de lembrar aqui que, independentemente de minha própria pessoa, o desenvolvimento posterior dessas duas posições, do historicismo de um lado, da ciência social histórica de outro, acabou aproximando-as. Na verdade, não existe mais nos dias de hoje aquele antagonismo, a briga já foi deixada para trás e hoje chegou-se à conclusão de que o mais interessante é ver o desenvolvimento do processo como um todo, no qual sempre surgem novas propostas, sem que o passado tenha que ser descartado. Trata-se de um constante processo de diferenciação, mas sempre dentro daquele contexto maior, que é o de uma ciência histórica única. 
6. RMPE: A crítica que o senhor acabou de fazer aos representantes da ciência social histórica, qual seja, a de que eles teriam simplificado demais as coisas para que pudessem ter uma imagem do inimigo a combater, foi feita, de maneira semelhante, também por Chris Lorenz (LORENZ 2004, p. 131 et se.). Para este autor, residiriam, também neste aspecto, entre outros, as razões da crise em que se encontra atualmente a ciência social histórica.

Ulrich Muhlack: Você acaba de tocar em um ponto que era muito importante naquele momento. É preciso, no entanto, que se faça uma diferenciação entre aspectos diversos daquela crítica. Até agora eu havia dito que o antagonismo entre os representantes do historicismo de um lado, e da ciência social histórica do outro, era um debate sobre métodos e temas historiográficos. Isto é, no entanto, apenas um lado da questão. O outro lado está relacionado ao fato de que os representantes da ciência social histórica apresentavam um programa político-ideológico específico. Eles eram defensores de uma democratização profunda na Alemanha. Poder-se-ia dizer que o almejado por eles era uma renovação democrática em moldes ocidentais. E eles censuravam no historicismo o fato de que ele teria estado ligado por décadas e décadas com os representantes do Nacionalismo, do Imperialismo, sem falar das ligações estreitas, supostamente estreitas, com o Nacional-Socialismo. Dito de uma outra forma, via-se o historicismo como uma carga política, da qual era preciso livrar-se. Este era um ponto muito importante para eles, e seu objetivo era o de fomentar a democracia na Alemanha através da ciência social histórica. Talvez eu esteja sendo um tanto drástico demais, mas este antagonismo político desempenhava um papel muito importante. E este fato me chamou mais uma vez a reagir, já que aquela crítica não era justa com o historicismo. Não se pode amarrar o historicismo a uma determinada tendência política. Johann Gustav Droysen era liberal-democrata, Leopold von Ranke e Jacob Burckhardt eram conservadores. Os autores historicistas do século XIX eram representantes das mais diversas posições políticas; existiram também autores historicistas de esquerda como Zimmermann, o qual escreveu uma História das Revoluções Camponesas. Se se fosse ordenar os historiadores historicistas do século XIX segundo sua posição política, chegar-se-ia a um espectro completo de todas as posições políticas, da direita a esquerda. Nesse sentido, a crítica política a ele era injusta. Se um determinado autor historicista se envolveu com o Nacional-Socialismo, isso não deve depor contra o historicismo, mas deve ser visto, isso sim, como uma questão relativa ao posicionamento político daquele autor. É preciso que se separe essas duas coisas. É claro que nem sempre é possível separá-las, de vez em quando elas acabam se entrelaçando. Mas até por uma questão de clareza conceitual, é preciso que se proceda assim. E isto é válido também, se me for permitido acrescentar aqui, para os representantes da ciência social histórica. Eles eram engajados politicamente, mas ao mesmo tempo eram cientistas corretos. Eles não faziam propaganda partidária, eles apenas realizavam suas pesquisas em moldes científicos, com seus novos métodos, seus novos interesses e suas novas propostas. Isso os diferenciava dos marxistas do Partido Comunista da 
República Democrática Alemã, os quais por vezes escreviam história segundo as regras ditadas pelos congressos do partido. Aqui se trata de algo bem diferente. Nesse caso, pode-se falar de história tendenciosa, de visão partidária. Mas, mesmo na República Democrática Alemã, sempre houve historiadores que se esforçaram, na medida do possível, por manter um espaço livre para suas pesquisas históricas genuínas. Trata-se, em todos estes casos, da procura de uma relação equilibrada entre história e política, entre a ciência e vida.

7. RMPE: Apesar de todos estes embates, quão produtiva foi para a ciência histórica alemã a renovação através da Ciência Social Histórica? Ela contribuiu e, em caso positivo, como ela contribuiu para o debate sobre o ofício do historiador? Na verdade o senhor já falou um pouco sobre esse tema, mas talvez possa precisar mais sua resposta...

Ulrich Muhlack: Por um lado, repetindo aqui o que já foi dito anteriormente, é um mérito da história social ou ciência social histórica, o fato dela ter conquistado sistematicamente novos campos para a pesquisa histórica, os quais não eram focados antes, ao mesmo tempo em que utilizava novos métodos e se relacionava interdisciplinarmente com a Economia, a Sociologia e a Ciência Política, de uma maneira que não havia sido feita até então. Isso fez com que a ciência histórica progredisse. A isso soma-se um outro ponto. Eu já mencionei aqui que os defensores do historicismo se sentiram desafiados pelos representantes da ciência social histórica. Em decorrência disso, houve na década de setenta, e eu mesmo participei dele, um grande debate teórico. Talvez esse tenha sido o resultado principal, ou seja, que a teoria da história tenha se tornado importante e tenha sido discutida em todos os seus aspectos. Tornamo-nos mais conscientes do que havíamos sido até então (no período em que nos sentíamos seguros em nossa prática científica) sobre os pressupostos teóricos da ciência histórica. Por exemplo, sobre a questão de como se relacionam ciência histórica e política ou, como a história pode ter relações com o presente e, ao mesmo tempo, evitar tornar-se história tendenciosa. Ou ainda questões de método, tais como a relação entre análise estrutural e análise individualizada, a relação entre política interna e política externa, entre história econômica e história política. Todas essas questões foram discutidas com uma sistematicidade, consequência e exatidão até então desconhecidas. Isso tudo nós devemos, sem dúvida alguma, a esse impulso.

8. RMPE: O senhor acaba de tocar em um ponto que remete a outra questão, que gostaria de abordar. $O$ senhor disse que todas aquelas questões foram muito discutidas. Delas surgiram muitos livros, os quais, até hoje, podem ser lidos com bastante proveito. No entanto, atualmente encontram-se, cada vez mais, defensores do ponto de vista de que está havendo um excesso de teoria e de discussões teóricas.

Ulrich Muhlack: Em primeiro lugar, gostaria de dizer que eu também tenho percebido esse fenômeno, e, em segundo, que partilho dessa crítica. Isso 
parece contradizer aquilo que acabei de dizer, mas na verdade, não é uma contradição. É preciso que se tenha bem claro em mente, qual é o sentido de se ocupar com teoria da história. Teoria da história não é um tema que se possa trabalhar separadamente, e que pertença a um mundo abstrato. Teoria de história não é nada mais que teoria da ciência histórica. Isto quer dizer que ela deve ser um instrumento de ajuda para o fazer prático desta ciência. Este é o ponto. Seu objetivo deve ser o de ser um guia para a pesquisa e o ensino de história. E, é por isso que, na prática, as reflexões teóricas são feitas em momentos em que novos problemas historiográficos, novos temas historiográficos, vêm à tona. Estes últimos é que levam à conclusão de que se tem uma necessidade de teoria e de se refletir teoricamente. Assim também ocorreu quando do surgimento da ciência social histórica. Isto pode ser exemplificado com o caso de Hans-Ulrich Wehler. Ele sempre foi um homem da prática. Ele escreveu trabalhos enormes de história, como por exemplo, uma História Social da Alemanha em cinco volumes, da Idade Moderna até 1990. Seu interesse teórico sempre esteve a serviço desse empreendimento historiográfico e se esgotou nele. Colocando em termos genéricos: existem épocas em que essa necessidade de teoria existe e, então, são organizadas discussões, são formados grêmios de estudo, são organizados encontros, são editados livros e, em algum momento, o tema se esgota. A partir daí, existe um grande perigo de que esses debates sejam prolongados de uma maneira artificial e se tornem um fim em si mesmo. Ou ainda que sejam protagonizados por profissionais, que não sejam historiadores e que não tenham uma relação próxima com a 20 prática da ciência histórica, dando-se a fazer elocubrações filosóficas abstratas, das quais não é feita nenhuma ponte para a prática. Aqui eu já citei Wehler como exemplo. Mas poderíamos também falar de Droysen. Ele era muito interessado em filosofia, foi um seguidor de Hegel e autor de uma Historik, a qual até hoje ainda é considerada um modelo. No entanto, ele era em primeiro lugar um historiador, o qual desenvolvia suas considerações teórico-históricas sempre em relação com seus interesses historiográficos práticos. Isso o diferencia de alguns teóricos da história de hoje em dia, os quais não têm interesses historiográficos práticos, permanecendo apenas no âmbito das abstrações.

9. RMPE: Gostaria de abordar agora mais especificamente um termo do qual já falamos aqui várias vezes: o historicismo. Um de seus livros, publicado em 1991, chama-se: A ciência histórica no Humanismo e no Iluminismo: a pré-história do historicismo. ${ }^{3}$ Por detrás deste título está implícito um significado específico do termo "historicismo", cujo uso o senhor mesmo põe em questão em textos posteriores, em que diz ser ele por vezes usado de maneira muito redutora, ou então muito ampla, banalizando-o. Como o senhor o definiria? ${ }^{4}$

Ulrich Muhlack: Esta é uma pergunta bastante justificada, já que se pode fazer um uso abusivo do termo historicismo e isto tem me levado, nos últimos tempos

3 Título original: Geschichtswissenschaft im Humanismus und in der Aufklärung. Die Vorgeschichte des Historismus.

${ }^{4}$ No alemão o termo a que me refiro é o do "Historismus", aqui traduzido como Historicismo. 
- isto eu posso afirmar agora -, a questioná-lo. A palavra "historicismo" assume hoje, muitas vezes, um significado hermético. Nesse sentido, ela significa um ensinamento ou edifício teórico fechado em si mesmo, de alguma forma idêntico à concepção de história do século XIX, talvez abrangendo o início do século XX, o qual poderia ser ultrapassado. Daí a expressão, usada na década de 1960, "ciência histórica para além do historicismo". Isto é uma redução do termo, a qual nada tem que ver com o significado original do mesmo, no momento de seu surgimento por volta de 1900, quando era usado por autores como Ernst Troeltsch ou Friedrich Meinecke. Para eles, o historicismo era muito mais que uma concepção da ciência histórica, a qual estaria naquele momento pronta e acabada, sendo antes uma revolução no pensamento sobre o humano, um fenômeno de dimensões enormes, o qual Troeltsch, com razão, denominou de "historicização", e que começa com a Revolução Francesa5. A historicização do pensamento a respeito das coisas humanas significa a descoberta do fato de que o humano não é explicável por nenhuma instância ou categoria externa a ele, e isto inclui a religião e a filosofia, mas sim que é pura e simplesmente histórico, que ele advém da história, que ele não é nada além da história. Que a única realidade que possuímos é nosso mundo histórico imanente, pelo qual somos responsáveis, pelo qual nenhuma outra instância é responsável e do qual nenhuma outra instância pode nos salvar. Isto é a experiência historizante desde 1800 e este processo não está concluído, como se tivesse estado em voga no século $X I X$ e depois tivesse sido perdido no século $X X$, mas, sim, continua até hoje e é um processo que nunca chegará ao fim, porque sempre existirão novos campos a serem historizados. Até hoje, por exemplo, os teólogos têm dificuldades com a historicização de sua própria história, com a historicização da história da Igreja. Ainda existem muitas, por assim dizer, zonas tabu, que se fecham para o processo de historicização, mas que serão abrangidos por ela em algum momento. Isto é o que entendo por historicismo. Historicismo é a historicização do pensamento humano e isto levou naturalmente a uma outra concepção de história, ou melhor dizendo, de ciência histórica. Até o advento do historicismo, a história era uma ciência auxiliar de disciplinas normativas, as quais tinham a tarefa de anunciar a verdade eterna: disciplina auxiliar da Teologia, da Filosofia, da Jurisprudência. Estas disciplinas anunciavam verdades gerais, as quais deviam ser exemplificadas através de material histórico concreto. Agora esta disciplina subordinada - a história - torna-se uma ciência independente; ela passa de uma disciplina auxiliar para uma disciplina autônoma, a qual não tem outro compromisso senão com o passado mesmo. Esse foi o nascimento da ciência histórica moderna e, com ele, foram dadas as suas bases, que perduram até hoje. Neste processo pode-se incluir tudo o que foi dito até agora; também a história social é um capítulo neste processo de historicização. Aqui foram conquistados campos para a história, os quais, desta forma, não existiam antes. Também o desenvolvimento mais recente não significa nada mais do que a 
conquista de novas áreas para a história, as quais até então estavam excluídas de seu âmbito, que não eram observadas, ou não suficientemente observadas.

10. RMPE: Mas, mesmo assim, não se pode negar que o termo Historicismo tem também um outro significado na história da historiografia: ele está diretamente relacionado com uma determinada vertente metodológica e temática do século XIX...

Ulrich Muhlack: Otto Hintze, um grande historiador da primeira metade do século $X X$, também via todo o contexto acima descrito da mesma forma que Troeltsch e, na minha opinião, ele tinha razão. Se se entende historicismo como um processo de historicização, todas as vertentes importantes do século XIX pertencem a ele. Há uma certa tendência a limitar o historicismo a Ranke e Droysen e talvez a Heinrich von Treitschke e historiadores pertencentes ao grupo próximo destas figuras, mas isto é incabível. Não se pode fazer isto. Até o marxismo é uma forma de historicismo. Aqui estou dilatando bastante os limites, já que também o materialismo dialético é uma tentativa de explicar o presente através da história. Da história das lutas de classes. Tudo bem, pode-se fazer objeções a esta inclusão, já que o materialismo histórico se tornou muito dogmático e a-histórico. Mas, a princípio, é bastante característico que Karl Marx e Friedrich Engels também argumentem historicamente. O capital é uma obra de economia política, mas nela tudo é explicado de maneira bem diversa daquela usada nos trabalhos dos pensadores da economia política do 22 século XVIII. Em outras palavras: nada nem ninguém consegue se manter de fora da correnteza historicizante. Se a tomamos por parâmetro, as diferenças passam para segundo plano. É claro que existem diferenças, se olharmos bem de perto. É óbvio que existem diferenças entre Ranke e Marx, entre Droysen e Henry Thomas Buckle, o representante do positismo inglês na historiografia. Mas é comum a todos eles a valorização da História, sua elevação à instância explicativa mais importante para as coisas humanas.

11. RMPE: O senhor acabou de citar o nome de Ranke, por ser ele frequentemente relacionado ao termo Historicismo. Em alusão à obra de Simmel O que significa Kant para nós? (1896), podemos nos perguntar: o que significa Ranke para nós hoje?

Ulrich Muhlack: Aqui eu posso conectar-me àquilo que acabei de dizer. Já tive a oportunidade de dizer que a experiência, nova naquele momento, de historicização, havia dado ensejo ao surgimento de uma nova ciência histórica. A disciplina História, que, até então, não passava de uma ciência auxiliar de outras disciplinas, sai desta relação de dependência e se torna uma disciplina autônoma, a qual só depende de si mesma, a qual cria seu próprio instrumentário e que não depende mais das regras ditadas por elas. Ranke pertence àqueles que personificam esta ciência histórica tornada autônoma. Ranke está entre aqueles que, por primeiro, criam e utilizam este novo conceito de ciência histórica em suas obras e aulas. Ranke não só produziu uma obra historiográfica imensa, como também foi professor universitário em Berlim por 
quase cinquenta anos, tendo sido ali o criador de um seminário de História, no sentido moderno do termo. Este seminário tinha a função de ser como um laboratório para o exercício do método histórico, ${ }^{6}$ e acabou por tornar-se uma célula-mãe da moderna ciência histórica na Alemanha e, até mesmo fora dela. Neste seminário, criado por Ranke, chegavam levas de estudantes, não só alemães, como também estrangeiros. Ranke tinha renome internacional. Um de seus alunos alí é Georg Waitz, o qual montará em Göttingen uma espécie de filial deste seminário rankeano, e que acaba tornando-se muito mais famoso que o do mestre, já que mais profissional, tecnicamente muito mais avançado. Também conhecido internacionalmente e com a mais alta reputação. Tudo isso está ligado ao nome de Ranke, todo este processo de surgimento da ciência histórica moderna. A isso, juntam-se os resultados concretos de sua historiografia. Ele produziu muitas obras sobre a história do sistema dos Estados europeus da Modernidade, ou seja, do Renascimento até a Revolução Francesa, transbordando, na verdade, estes limites temporais, chegando até o século XIX. Ele trabalhou toda esta temática de maneira totalmente nova desde suas bases, de acordo com um programa de pesquisas por ele criado. É claro que teve precursores. Nada surge sem pressupostos na história. Mas ele trabalhou o material de uma maneira tal que acabou por criar uma nova base. E pode-se acrescentar aqui que o que ele descobriu sobre o desenvolvimento dos Estados europeus modernos, sobre a França, sobre a Inglaterra, sobre a Prússia, não está ultrapassado. Está lá, da maneira que ele deixou, como base para pesquisas posteriores. Não se pode reprovar, em Ranke, que ele não tenha vivido no século $X X$, que não tenha estado consciente dos desafios do século XX. Nós vivemos em um outro momento. Ranke viveu no século XIX. Mas, aquilo que escreveu no século XIX, de acordo com o horizonte vigente em seu tempo, perdurou mais do que o que escreveram outros historiadores. Um último ponto ainda sobre Ranke, o qual nos leva de volta a um tema sobre o qual já conversamos. Ranke foi um historiador excepcionalmente reflexivo. Ele não foi um teórico, no sentido de que teria escrito obras teóricas, ou de ter dado aulas sobre teoria de história. Mas ele leu tudo o que era importante. Ele leu Hegel, ele leu Fichte, ele leu Kant. Ele conhecia todos estes autores. O fato de ele não ter escrito sobre temas semelhantes tem uma razão muito simples. Ele tinha uma certa desconfiança com relação a qualquer tipo de reflexão teórica, a qual fosse feita separadamente da prática historiográfica. Isso ele não aceitava. 0 que ele fez ao invés disso: ele inseriu todo o seu interesse teórico e seu potencial reflexivo em suas obras históricas. Suas obras não são, de maneira alguma, meras coleções de material, mas sim refletidas da primeira à última página. Elas se constituem em um trabalho magistral de reflexão, um produto de suas reflexões sobre história. Isto é perceptível. Ranke nunca comunica meros fatos, mas sim julgamentos sobre eles. Os fatos são narrados de tal maneira que o seu julgamento se torne claro. Isto, poderíamos assim dizer, é teoria que se tornou imanente à prática da pesquisa histórica. Nesse sentido ele foi teórico. E só para

${ }^{6}$ Método de análise crítica das fontes. 
se fazer uma observação breve aqui: o que é teoria? O que significa teoria, no sentido estrito do termo? Teoria significa observação pensante, na verdade, pensar mesmo. E como o melhor historiador deve ser considerado aquele historiador que consegue expor reflexivamente seus objetos de estudo. É óbvio que é bastante útil, que ocasionalmente se discuta as questões teóricas separadamente. Trata-se aqui, no entanto, de uma separação didática, de uma separação por razões práticas. Mas em última instância, teoria e prática devem andar sempre juntas e serem, sempre, relacionadas uma à outra. Ranke é um bom exemplo desta unidade, deste entrelaçamento entre teoria e prática na historiografia.

12. RMPE: Mais um aspecto relacionado a Ranke, que gostaria ainda de tematizar aqui. Wolfgang Hardtwig e o senhor também relacionam o nome de Ranke com o processo de estetização da escrita da História. O senhor pode tecer algumas considerações sobre este ponto?

Ulrich Muhlack: Ranke tinha pretensões literárias, mas pretensões literárias de um tipo novo. Pode-se dizer que, até o final do século XVIII, ou seja, até o advento do historicismo, a História era um gênero literário, que, como qualquer outro, devia ser escrito de acordo com as regras da Retórica. Ranke não pode ser visto em conexão com este tipo de literatura retórica. Na verdade, ele declarou guerra contra este tipo de escrita da história. Mas, também é correto afirmar que ele tinha, por assim dizer, a ambição de apresentar os resultados de sua pesquisa histórica com requinte 24 literário. Só que não mais segundo as regras da Retórica, mas sim de modo que, tudo o que ele havia pesquisado e tudo o que correspondia às suas exigências relativas à verdade histórica, fosse exposto de uma maneira apropriada. Ele postulava uma estética, a qual deveria corresponder à lógica do conhecimento histórico. A lógica do conhecimento histórico deveria ser transposta para a exposição histórica. Droysen conseguiu expressar isto de maneira clara: a escrita da História deveria apresentar-se como uma obra-de-arte lógica. O leitor deveria poder deleitar-se com uma argumentação correta e com uma exposição bem escrita. Neste sentido, Ranke foi um grande advogado da exposição histórica com ambições literárias. Ele sempre teve o desejo de escrever tão bem quanto um autor de romances. Sobre sua primeira obra, as Histórias dos povos românicos e germânicos, ele chegou a dizer que teria sido sua ambição escrevê-la de tal maneira que ela pudesse concorrer com um romance de Walter Scott. Porém, sempre tendo como ideia reguladora, como pensamento de fundo, que nada além do conhecimento histórico em si mesmo deveria estar transposto na exposição e que a beleza a ser encontrada nela deveria ser a beleza própria do pensamento histórico.

13. RMPE: Um de seus últimos cursos na Universidade de Frankfurt se chamava "Sobre a utilidade da História para o presente". Nele, o senhor trabalhou com a visão sobre esta questão em autores desde a Antiguidade (Heródoto, Tucídides), passando pela Idade Média (Otto von Freising), pelo Iluminismo (Schiller) até chegar aos séculos XIX e XX (Ranke, Nietzsche, Vossler e Koselleck). Como o senhor se expressaria sobre este tema? 
Ulrich Muhlack: Nós já conversamos sobre muitos aspectos desta questão, mas é bom que você a coloque desta forma. Este tema "sobre a utilidade da história para o presente" deveria remeter a Nietzsche, a seu famoso texto "Da utilidade e desvantagem da História para a vida". A "desvantagem" foi deixada de lado no título do curso, mas eu gostaria aqui de falar primeiramente sobre ela, para deixar claro o que ela significa. Nietzsche via o consumo excessivo de história como prejudicial para a vida. Este era seu pensamento: o excesso de história, nos casos em que as pessoas ocupavam excessivamente suas cabeças com conhecimentos e fatos históricos, tornava-as inaptas para o presente, para a vida. Para ele, a vida dependeria de uma imediatez das decisões e da vontade. Em meu curso tive o objetivo de tornar clara a utilidade da história para o presente. A própria questão colocada no título já dá, de certa forma, a resposta: a história, enquanto passado, não existe por si, mas sim para o presente, e isto pelo simples fato de que, como diz Benedetto Croce, a história é presente. O historiador vive no presente, ele formula suas opiniões sobre o passado no presente. Todo julgamento do historiador, todo livro que escreve é um pedaço do presente, é presente mesmo. É preciso que se esteja ciente disto. Não é que a História tenha relação com o presente, ela é presente. No momento em que penso historicamente, estou me movimentando no presente. Traduzindo para uma linguagem menos abstrata: o presente tem uma relação de dependência com a história, já que ele constituiu-se historicamente, ele tem suas raízes no passado. Isto é válido não apenas para a política, como também para a educação. Isto é válido para tudo: para nossa língua, para nosso vestuário, para a religião, para o campo das artes e assim por diante. Para o historiador resulta, disso tudo, o fato de que ele deve servir ao presente: ele deve instruir o presente sobre suas raízes no passado, sobre seus pressupostos históricos; ele deve mostrar ao presente de qual passado este advém. O historiador nunca poderá dizer às pessoas no presente como devem agir no futuro, ou mesmo o que elas podem fazer no presente para o futuro. Isto continua sendo de sua própria responsabilidade. Este, na verdade, é o ensinamento do Idealismo: que nós somos livres, que nós podemos nos autodeterminar, que nós mesmos somos nossa pré-condição. O historiador pode nos explicar sobre o que ocorreu até ontem, até uma hora atrás. Este é o campo temporal que não pode mais ser modificado, que permanece imutável diante de nossos olhos e que pode ser analisado.

\section{RMPE: O "hoje" pertence ao mundo da Ética.}

Ulrich Muhlack: Claro. O "hoje" pertence ao âmbito das decisões práticas e éticas. O passado está fora do âmbito de nosso poder ético-político. Eu não posso mais impedir Hitler de agir. Não faz sentido xingar os "malignos" da história, isto não leva a nada. Eu não estou em condições de mudar nada; eu só posso compreender, eu posso explicar, e esta é a grande tarefa do historiador: dizer-nos exatamente, logicamente, de maneira clara, como certas coisas aconteceram e de que circunstâncias elas resultaram. Isto não tem nada a ver com ética ou moral, isto é uma questão pertencente ao âmbito da lógica e do conhecimento. Aqui o historiador deve dar o máximo de si e ele está apto a fazê-lo. Muitas vezes 
é dito a ele que ele não estaria em condições de fazê-lo, que ele não estaria em condições de livrar-se de seus preconceitos. Isto é verdade até um certo ponto. Mas sempre houve historiadores que conseguiram se livrar de seus preconceitos em favor de seu trabalho cognitivo. Ranke, por exemplo, conseguiu, apesar de detestar as revoluções, analisar a Revolução Francesa. Ele vivenciou a Revolução de 1848 e se indignou com ela. Mas depois que ela já havia ocorrido, tendo se tornado, assim, objeto de suas investigações, ele procurou explicar logicamente o que ele havia rejeitado no momento anterior. Esta é a tarefa do historiador. No presente, ao contrário, tem-se que tomar decisões práticas.

15. RMPE: Entendo, mas como historiador tem-se mesmo assim a esperança, na medida em que grande parte dos fatos do passado esteja esclarecido ou explicado, de que se possa tomar decisões "mais corretas" no presente...

Ulrich Muhlack: Como historiador você pode expor a queda do muro na Alemanha, em 1989. Mas pode-se tirar consequências totalmente diversas deste fato. Um comunista tirará consequências bastante diferentes daquelas de um liberal-democrata, um nacionalista, outras diversas daquelas, tiradas por um defensor da ideia de Europa. Todas estas são posições ético-políticas. O historiador não deve ter aqui nada para dizer. Aqui a questão é a de nossa liberdade e de nossa consciência. É claro que nós vivemos em ordens normativas, nós temos leis e regras que regulam nossa conduta, correspondentes às ideias 26 vigentes em nosso tempo. Mas tudo isto é apenas o pano de fundo, o qual não livra os indivíduos de tomarem suas decisões. Também os Dez mandamentos, um dos documentos mais antigos no qual normas para a convivência humana são expostas, não impediram que se tenha sempre ido contra eles. Dito moralmente: à humanidade pertence o "bom" e o "mau", isto é, sua liberdade. A tarefa do historiador, por sua vez, consiste, em um momento posterior ao ocorrido, em compreender, em contextualizar, enfim, em transformar em conhecimento aquilo que no passado apareceu como "bom" e como "mau". A este movimento de compreensão pertence também a percepção de que, na história, muitas vezes o "bom" e o "mau" se condicionam e que, por isso, na análise, não devem ser vistos separadamente. Na verdade, esses dois termos não devem ser usados pelo historiador, já que eles não correspondem à unidade do acontecido.

\section{RMPE: Isso pertence novamente ao universo da Moral.}

Ulrich Muhlack: Exatamente, só para deixar mais claro através de um exemplo: lamenta-se constantemente a intolerância horrível da época das guerras religiosas, ocasião em que os católicos e os protestantes se arrancavam as cabeças e praticavam massacres uns contra os outros. Realmente, analisando-se estes fatos do ponto-de-vista atual, não foi uma época agradável. E, exatamente por isso, parece-nos ainda mais formidável a ascensão do Iluminismo, da tolerância. Esta é, no entanto, uma visão dicotômica da história: da escuridão surge a luz. O historiador chegará, do seu ponto-de-vista, à conclusão de que foi o excesso 
de intolerância, por exemplo, durante a Guerra dos Trinta Anos, a pré-condição para que a tolerância se tornasse possível no horizonte mental das pessoas. Não existe tolerância sem a necessidade de que ela seja exercitada. Até então não havia a noção da tolerância. Existiam começos. Tolerância, no sentido completo do termo, só se tornará possível, quando não se estiver mais disposto a suportar a intolerância religiosa. Até então, todo mundo havia acreditado na verdade absoluta. Lutero acreditava na verdade absoluta, Calvino acreditava na verdade absoluta, a Igreja Católica acreditava na verdade absoluta. Era-se, na verdade, obrigado a aniquilar o opositor, pois senão estar-se-ia traindo sua própria verdade. Isso era absolutamente lógico e correspondia à mentalidade daqueles tempos. Mas, em algum momento, a intolerância tornou-se excessiva para a maior parte das pessoas. E esse foi o momento do nascimento da tolerância: uma virada na história do pensamento. Muitas vezes percebe-se na história que aquilo que é oposto do ponto-de-vista moral, na verdade, deve ser pensado conjuntamente e se condiciona mutuamente.

17. RMPE: Agora gostaria de voltar-me para um tema bem diferente: na ciência histórica parece estar ocorrendo atualmente um renascimento dos estudos biográficos. O senhor já orienta há muito tempo estudos biográficos sobre historiadores. Como o senhor avalia a importância deles para a História da Historiografia?

Ulrich Muhlack: Esta pergunta me toca bastante de perto mesmo. Um de meus campos de pesquisa há décadas, poderia dizer assim, é a história da ciência histórica na Alemanha no século XIX, ou seja, sob os auspícios do já comentado historicismo. Eu publiquei um livro que trata da Pré-História dele, mas eu gostaria, muito mesmo, de não ficar apenas na Pré-História e, sim, de, no futuro, publicar um segundo volume e, talvez, até um terceiro. Não tê-lo feito até agora deve-se ao fato de ter-se tornado clara para mim, ao longo do tempo, a enorme complexidade desse tema. De qualquer forma, eu aprendi que é preciso que se possa apoiar em trabalhos anteriores para que se possa realizar um trabalho expositivo abrangente. Sobretudo os historiadores mais importantes do período devem já ter sido estudados individualmente, já que cada historiador é uma unidade constitutiva da ciência histórica de seu tempo. Quando se estuda um historiador individualmente, aprende-se não somente sobre ele, sua obra, seus pontos-de-vista, suas atividades, mas sim sobre todo o contexto no qual ele viveu, a escola em que estudou, a universidade em que esteve, a rede de ligações da qual ele mais tarde fez parte, as tradições das quais ele participou. Se ele tinha interesses políticos, junta-se a todo este contexto, ainda, a história política de seu tempo e, então, somos praticamente introduzidos a ela. Em resumo, de cada historiador individual abre-se um olhar concreto sobre o geral. Os estudos individuais sobre historiadores específicos são, portanto, um trabalho imprescindível, que deve ocorrer anteriormente a que se proceda a uma grande síntese sobre a história da historiografia. É claro que, da mesma maneira, é preciso que o historiador-biógrafo tenha um conhecimento bastante amplo da história do período para que possa escrever este tipo de biografia. Trata-se, aqui, de uma relação de condicionamento mútuo. 
18. RMPE: No Brasil os estudos em história da historiografia são um campo relativamente jovem, ou melhor dizendo, pouco explorado. Isto significa, para o interessado neste assunto, que são raras tanto as exposições panorâmicas sobre escolas e tendências historiográficas e seu desenvolvimento no tempo, como também os estudos biográficos sobre historiadores. O que o senhor aconselharia a nós historiadores interessados neste campo? Por onde deveríamos começar?

Ulrich Muhlack: É bastante difícil para mim responder esta questão, já que o tema não me é familiar. Me parece que seria aconselhável marcar as grandes épocas e questionar as relações com a história política. Na Alemanha estas relações são evidentes. Aqui a Revolução Francesa desempenhou um papel bastante importante, depois também as Revoluções de 1830 e 1848, a unificação dos estados alemães, as consequências da Primeira Guerra Mundial e assim por diante. Sempre foram as experiências marcantes do presente que deram origem a grandes desenvolvimentos na ciência histórica. É de se supor que o mesmo seja válido para o Brasil. É claro que não se pode explicar o desenvolvimento na história da historiografia somente com base na história política ou nos interesses do presente; no entanto, tais impulsos sempre desempenham um papel importante. De qualquer forma, também aqui é válida a máxima de que história é presente, de que as questões historiográficas surgem sempre no presente. Droysen foi marcado pela luta pela unificação alemã. Depois da Primeira Guerra Mundial os historiadores alemães voltaram-se para o tema da "mentira sobre a responsabilidade pela Guerra" do Tratado de Versalhes. Depois da Segunda Guerra Mundial foi importante para muitos historiadores alemães a questão do enfrentamento do passado. Quais foram as experiências do presente que marcaram o desenvolvimento da ciência histórica no Brasil? Qual foi o papel desempenhado, por exemplo, pela Independência? Ela despertou um interesse especial pela História? Pode-se perguntar, neste contexto também, quais os efeitos que um historiador estrangeiro como o alemão Heinrich Handelmann com sua História do Brasil veio a desencadear entre os historiadores brasileiros. A ciência histórica alemã, naquela época, era conhecida mundialmente. Handelmann pode ser visto, de certa forma, como um mensageiro dela. Tais influências externas sempre existiram na história da historiografia. Basta pensar no papel desempenhado pelos historiadores italianos na época do Renascimento.

19. RMPE: Já que estávamos falando sobre a historiografia alemã, gostaria de voltar a ela. Enquanto autor de balanços bibliográficos para várias revistas científicas como a Historische Zeitschrift, Geschichte in Wissenschaft und Unterricht $e$ Zeitschrift für historische Forschung, o senhor tem observado atentamente $o$ seu desenvolvimento desde os anos setenta. $O$ último destes balanços, no entanto, já é de catorze anos atrás. Como o senhor vê o desenvolvimento nos últimos anos. Há novas tendências? Como o senhor as avalia?

Ulrich Muhlack: É claro que existem novas tendências e isto por uma razão muito simples: porque existem novos questionamentos, novos campos temáticos. 
A ciência histórica é uma ciência voltada para a pesquisa. O tempo em que ela administrava um arsenal fixo de conhecimentos, o qual era repassado para as gerações seguintes, já ficou para trás. Desde que o Historicismo trouxe à tona a ideia de pesquisa no sentido moderno, tem-se a situação de que, as novas experiências do presente e as novas maneiras de se colocar os problemas sempre trarão consigo novos conhecimentos. As novas tendências, tema de sua pergunta, poderiam, até certo ponto, serem todas subsumidas dentro da expressão "história cultural", a qual está em uma relação de oposição tanto com a história política tradicional, como com a história estruturalizante da ciência social histórica. Seu objeto de estudo é o homem, em todas as suas manifestações. Neste contexto, o indivíduo é redescoberto, mas não no sentido da biografia tradicional, a qual se ocupava normalmente com as "grandes" personalidades, e sim, enquanto pertencente à massa de indivíduos sem nome. Isto é, sem dúvida alguma, um novo campo temático, o qual certamente requer novos métodos de pesquisa. Mas este novo campo temático não foge do contexto de uma ciência da história. Trata-se de um enriquecimento da ciência histórica e não de uma destruição da mesma, ou de uma troca de paradigmas. Hoje em dia fala-se muito em troca de paradigmas, até em trabalhos de doutorado. Isto é um disparate. A última troca de paradigmas na ciência histórica foi a entrada em cena do historicismo, por volta de 1800. Esta foi, de fato, uma troca de paradigmas. Ali foi posta abaixo uma velha tradição historiográfica europeia, a qual havia existido desde a Antiguidade. Mesmo ali foi dado continuidade a muita coisa que havia existido até então, foi retomada muita coisa, só que de uma maneira nova. O que nós estamos presenciando neste momento são apenas novos interesses, novas modas no campo da pesquisa, as quais, por sua vez, darão lugar no futuro a outras novidades e que não chegam a tomar o espaço de ninguém. Até mesmo a velha história política não foi ainda expulsa do horizonte do historiador. Agora mesmo estamos entrando novamente em um contexto de relações multipolares entre os Estados, de reaparecimento de velhos conflitos, aos quais se juntam outros novos. Nesta situação, voltamos a pensar na história das relações internacionais, a qual, por um longo período, tinha sido vista como obsoleta. Nada do que serve para nós hoje é obsoleto. Neste sentido, a situação atual na ciência histórica pode ser caracterizada como a de uma grande pluralidade de propostas, as quais não se excluem mutuamente. Por isso mesmo, não se tem hoje grandes conflitos teóricos. O que se tem hoje é uma coexistência de propostas diversas, e isto corresponde exatamente à lógica do ocorrido nas últimas décadas. Só poderíamos falar de uma troca de paradigmas, hoje, se se impusesse no mundo a visão de que não precisamos mais de história, de que ela não nos interessa mais, já que vivemos em um mundo moderno e tecnicizado, no qual não queremos nos incomodar com coisas velhas. Na verdade, não estamos livres de que isto venha a acontecer. A descoberta de história não significa que a vitória da visão de mundo historicizante vá permanecer para sempre. Pode ser que este nosso mundo, marcado pela cultura histórica, um dia desapareça. Mas, por enquanto, isto ainda não está em nosso horizonte. Nenhuma das novas tendências na ciência histórica tem uma tal proposta. 
20. RMPE: Mas entre os representantes da História Cultural e os da História Social na Alemanha houve já alguns conflitos...

Ulrich Muhlack: Sim, é claro. O panorama que acabo de esboçar é, na verdade, uma visão harmonizante, que só se tem quando se olha de cima. Mas é que só assim podemos ver semelhanças, que são perdidas de vista no calor da hora. É claro que faz uma grande diferença se me ocupo com história política ou com história do cotidiano. Também é correto que, sempre que se abre um campo novo de pesquisas, exista a necessidade por parte dos seus representantes de se distanciar polemicamente de propostas existentes anteriormente. Porém, na verdade, trata-se de campos de conhecimentos diversos uns dos outros, que não devem ser vistos em relação de oposição. Treitschke não se interessou, ou não se interessou primordialmente, pela história do cotidiano, porque seu tema era a questão nacional. O interesse atual pela história do cotidiano é o resultado de uma constelação política específica, a qual tem suas raízes no mundo das iniciativas privadas, dos interesses regionais, enfim, de experiências concretas de vida. Não faz sentido censurar nos historiadores da virada do século XIX para o $X X$, que eles não tenham tratado em seus estudos de campos que só chamaram a atenção para si cem anos depois, em razão de experiências totalmente novas do presente. Foi preciso a questão social, por volta de 1900, para que a escravidão antiga fosse redescoberta como objeto da pesquisa histórica. O próprio caminhar, o tornar-se da história, sempre produz novas questões.

Eu gostaria, no entanto, de lembrar aqui uma outra coisa: que as obras de bons historiadores não envelhecem. Tucídides não foi superado até hoje. Pode-se descobrir novos materiais arqueológicos; no entanto, no geral sua obra permanece uma obra-prima, a qual sempre permanecerá. O mesmo vale para Ranke e outros historiadores. Nunca irei me esquecer como Alfred Heuss apresentou a bibliografia em uma aula sobre história da Grécia: veementemente mesmo, ele só aconselhava dois autores mais velhos: Eduard Meyer e Karl Julius Beloch. Eles tinham, independentemente um do outro, trabalhado em suas obras sobre a história da Grécia nos períodos Arcaico e Clássico, exclusivamente com fontes primárias; este desempenho deles parecia a Heuss insuperável. E de fato: não é preciso fazer sempre tudo de novo. Existem trabalhos historiográficos os quais não envelhecem, mesmo que a pesquisa especializada vá além deles.

21. RMPE: Pode-se dizer, então, que a obra clássica permanece e, mesmo assim, pode ser que surja um outro clássico sobre um mesmo tema, no caso de um outro historiador ter descoberto novas fontes ou desenvolvido novos métodos para velhas fontes...

Ulrich Muhlack: Mas eu diria até que, quando se trata de obras de caráter geral, geralmente deve ser dada preferência às obras mais velhas. Pode-se aprender mais de uma obra de Droysen, a qual foi escrita em uma linguagem cuidada e a partir de uma questão claramente delimitada, do que de um trabalho moderno, escrito em uma linguagem confusa. Não faltam exemplos de trabalhos 
modernos nos quais a falta de precisão linguística é latente. Trata-se, nesses casos, com frequência, de trabalhos feitos de compilações de textos teóricos ou pseudoteóricos nos quais o tema tratado é obscurecido até o ponto da ininteligibilidade. Autores mais antigos são simplesmente muito melhores neste aspecto. Gostaria de acrescentar a isto apenas uma observação sobre a relação entre linguagem e pensamento. Quem consegue pensar de forma consequente, quem conhece seu objeto realmente e sabe o que quer expressar sobre ele, com certeza escreverá bem, ou pelo menos de maneira inteligível. Uma frase mal formulada revela o fato de que o tema não foi refletido suficientemente. $E$, suficientemente refletido foi um tema se ele pode ser transposto de maneira clara e compreensível para o papel. Estas duas coisas condicionam-se mutuamente. Este era um tema importante para Ranke. Para ele, era imprescindível que o historiador expusesse seu pensamento de tal maneira, que ele se tornasse claro enquanto pensamento, sem que fosse acrescentada qualquer coisa a ele, fosse um ensinamento moral ou um enfeite retórico. Esta é a estética do texto histórico sob o auspício da moderna ciência histórica. Todo historiador deve perguntar-se como ele pode expressar suas ideias da maneira mais simples possível, sem que seja retirado delas nem um pouquinho de sua exatidão. Uma tarefa passível de ser executada e que só exige esforço. A historiografia inglesa pode figurar aqui como modelo. Ela é pouco carregada de teoria, ela vai muito pragmaticamente ao tema e tende a usar uma linguagem clara. Algumas traduções de textos alemães para o inglês são melhores que o original. Falo isto por experiência própria. Aqui entramos em contato com um velho pensamento humanista: o de que a verdade é, necessariamente, bela, assim como o moralmente bom é belo. Não nos expressaríamos desta forma hoje, mas o pensamento de base permanece correto e isto, principalmente, para nós historiadores. Deve-se, neste aspecto, tentar copiar os poetas e os bons escritores. Os historiadores devem ler muito, ler literatura, ter contato com o mundo das letras, para que possam ter uma noção das possibilidades de sua língua. Ranke o fez, ele foi um conhecedor exímio da literatura de seu tempo. Hoje isto já não é considerado uma obviedade. Não se pode mais partir do princípio de que estudantes, na iminência de se tornar historiadores, sejam grandes conhecedores de literatura ou da literatura clássica.

22. RMPE: Para finalizar nossa conversa, gostaria de perguntar-lhe sobre seus projetos para o futuro. Quando se lê a lista de suas publicações, percebe-se bem depressa que o senhor tem trabalhado bastante depois de sua aposentadoria e até publicado mais que antes dela. O senhor ainda está trabalhando em algum, ou ainda tem em mente, grandes projetos?

Ulrich Muhlack: É próprio da natureza das coisas que o tempo para grandes projetos vá encolhendo; a gente ignora isto e pode ignorar por um tempo, mas tem que dar um jeito de começar a concentrar-se. No momento estou escrevendo um pequeno livro sobre o Renascimento e o Humanismo na Alemanha. Fará parte da série Enciclopédia da História Alemã e está me dando a oportunidade de resumir 
estudos feitos no passado e pesquisas realizadas para o preparo de minhas aulas. Além disto, espero realmente chegar a escrever a obra sobre o historicismo e a ciência histórica moderna na Alemanha no século XIX. As pesquisas de base já estão prontas, só falta agora juntar tudo e dar um certo acabamento.

23. RMPE: Se o senhor me permite fazer uma sugestão, talvez fosse bastante proveitoso para todos nós, interessados em história da historiografia, se o senhor, antes de completar esta grande obra, escrevesse um ensaio topográfico sobre a ciência histórica alemã no século XIX...

Ulrich Muhlack: Você quer dizer com ensaio topográfico os lugares e as universidades nas quais as diferentes tendências da ciência histórica alemã se formaram. Na verdade, isto pode e provavelmente será feito juntamente com esta obra que estou planejando, mesmo que o mais desejável fosse que se realizassem estudos individuais sobre cada uma daquelas tendências. Um de meus temas nesta obra é a chamada Escola Política, constituída pelos historiadores que combinaram de uma maneira especial política e história; esta tendência coincide em grande parte com a Escola de Heidelberg. A Escola de Ranke, ou seja, a escola dos "objetivistas", a qual subsume ciência histórica ao uso estrito do método crítico de análise das fontes, tem sede em Berlim. Mas Berlim é, devido à estratégia de recrutamento de pessoal feita por burocratas do Ministério da Cultura, eles mesmos estudados e cultos, mais que isto. Em 32 Berlim está não somente Ranke, mas também Droysen; não somente Hegel, mas também seus opositores. Droysen atuou ao lado de Ranke, apesar dos dois não terem sido grandes amigos. Berlim foi mesmo um centro do historicismo alemão; ali encontraram-se quase todas as principais tendências dele, como por exemplo, os representantes das ciências da Antiguidade, entre eles August Boeckh e Theodor Mommsem, ou também o germanista Jacob Grimm, cujo vínculo era com a Academia de Ciências, mas que tinha também a possibilidade de lecionar na Universidade. Finalmente Savigny, o líder da Escola Histórica do Direito. Poderíamos concentrar a história da Ciência Histórica na Alemanha no século XIX em Berlim, para depois, partindo dali, seguir as principais linhas pelo restante da Alemanha. Da mesma forma que seria possível escrever a história da historiografia iluminista alemã partindo-se de Göttingen, já que tudo acontecia ali. Isto acontece de vez em quando, são lugares excepcionais. É bastante interessante.

24. RMPE: Todos estes são pontos de partida muito interessantes para estudos futuros. Mas talvez faltem pessoas que os realizem...

Ulrich Muhlack: Sobre Berlim foram publicadas algumas coisas recentemente. Por ocasião do aniversário de 200 anos da Universidade foram publicados muitos volumes, nos quais foram feitas as honras ao papel desempenhado por Berlim para cada uma das ciências. Ali encontram-se bons artigos também relativos à ciência histórica. No entanto, uma história-problema sobre o historicismo 
alemão, que tome Berlim como ponto de partida, seria algo bem diverso de uma obra comemorativa. Mas, como já disse acima, em minha obra acompanharei o desenvolvimento no tempo das principais tendências do historicismo alemão. Vou começar pelas ciências da Antiguidade Clássica, para as quais Friedrich August Wolf e August Boeckh são representativos. A seguir vem a filosofia do idealismo alemão, a qual deu à jovem Ciência Histórica noções filosóficas de valor incalculável. Droysen entendia sua Historik como crítica da razão histórica; ele leu, assim como Ranke, toda a obra de Kant. O idealismo alemão está, no entanto, ligado ao historicismo, principalmente pelo fato de ter feito da história o principal objeto de suas reflexões. A terceira linha que acompanharei será a da Nova Escola da História Antiga, de Niebuhr até Mommsem. A ela conecta-se Ranke. Depois vêm as escolas históricas da Economia, de Wilhelm Georg Friedrich Roscher a Karl Knies, os historiadores políticos, os historiadores da cultura, pelo menos os que existiam na época, Jacob Burckhardt por exemplo e, além deles, os historiadores da arte. Por último vêm a historiografia católica e a protestante, ou seja, aqueles historiadores de religiosidade marcada. Sobre quase todas essas tendências tenho já trabalhos ou artigos escritos, os quais só devem agora ser reunidos em uma grande obra sintetizadora. Este é, portanto, meu grande projeto para o futuro.

\section{Referências bibliográficas}

HARDTWIG, Wolfgang. Die Verwissenschaftlichung der Historie und die Ästhetisierung der Darstellung. In: KOSELLECK, Reinhart; LUTZ, Heinrich;

RÜSEN, Jörn (Hg.). Formen der Geschichtsschreibung. München: DTV 1982 (Theorie der Geschichte. Beiträge zur Historik, Bd. 4)

LORENZ, Chris. Wozu noch Theorie der Geschichte? Über das ambivalente Verhältnis zwischen Gesellschaftsgeschichte und Modernisierungstheorie. In: DEPKAT, Volker; MÜLLER, Mathias; SOMMER, Andreas Urs. Wozu Geschichte(n)? Stuttgart: Steiner Verlag, 2004.

MUHLACK, Ulrich. Geschichtswissenschaft im Humanismus und in der

Aufklärung: die Vorgeschichte des Historismus. München: Beck, 1991.

NIETZSCHE, Friedrich Wilhelm. Da utilidade e desvantagens da História

para a vida. Tradução de Noéli Correia de Melo Sobrinho. Rio de Janeiro: Editora PUC-Rio, 2005.

SIMMEL, Georg. Was ist uns Kant? In: SIMMEL, Georg; DAHME, Heinz-Jürgen.

Gesamtausgabe, Bd. 5, Frankfurt am Main: Suhrkamp, 1992.

TROELTSCH, Ernst. A crise atual da história. In: MALERBA, Jurandir (org.) Lições

de História: o caminho da ciência no longo século XIX. Rio de Janeiro;

Porto Alegre: FGV; EdiPUCRS, 2010, p. 448-457. 